\title{
AKURASI
}

\section{DETERMINAN KUALITAS LAPORAN KEUANGAN SATUAN ORGANISASI PERANGKAT DAERAH}

\author{
Mirnawati ${ }^{1}$, Ema Nirwana $^{2}$, Decky Hendarsyah ${ }^{3}$ \\ ${ }^{123}$ Sekolah Tinggi Ilmu Ekonomi (STIE) Syariah Bengkalis, Riau, Indonesia \\ ${ }^{2}$ Corresponding author: halbysharkan@gmail.com (iD -
}

\section{INFORMASI ARTIKEL ABSTRAK}

Article history:

Dikirim: 31/12/2020

Revisi pertama: $20 / 04 / 2021$

Diterima: 05/05/2021

Tersedia online: $d d / m m / y y y y$
Studi ini bertujuan untuk menganalisis pengaruh kompetensi staf akuntansi (KSA), standar akuntansi pemerintah (SAP), sistem pengendalian internal (SPI) dan pemanfaatan teknologi informasi (PTI) terhadap kualitas laporan keuangan (KLK) pada pemerintah daerah Kabupaten Bengkalis. Studi ini dirancang menggunakan metode deskriptif kuantitatif dengan sumber data primer dan sekunder, dimana data dihimpun melalui kuesioner dan studi pustaka. Populasi dari studi ini adalah pegawai yang bekerja pada sub bagian keuangan dan perlengkapan seluruh satuan organisasi perangkat daerah Kabupaten Bengkalis. Sampel penelitian menggunakan metode proportional sampling dengan jumlah 153 orang. Studi ini mendapatkan hasil bahwa KLK dipengaruhi secara signifikan oleh KSA, SAP, SPI dan PTI. Hasil ini menunjukkan bahwa pemerintah daerah Kabupaten Bengkalis dapat meningkatkan kinerja dan mempertahankan opini audit wajar tanpa pengecualian dari Badan Pemeriksa Keuangan (BPK) dan tergolong kedalam pemerintah yang bersih dan sehat.

Kata Kunci: kualitas, kompetensi, akuntansi, pengendalian, teknologi informasi.

\section{ABSTRACT}

This study aims to analyze the effect of accounting staff competence (ASC), government accounting standards (GAS), internal control systems (ICS), and the use of information technology (UIT) on the quality of financial reports (QFR) in the regional government of Bengkalis Regency. This study was designed using quantitative descriptive methods with primary and secondary data sources, where data were collected through questionnaires and literature study. The populations of this study were employees who worked in the sub-division of finance and equipment for all organizational units in the Bengkalis Regency. The sample in this study used a proportional sampling method with a total of 153 peoples. This study found that partially and simultaneously ASC, GAS, ICS, and UIT had a significant effect on QRF. So that with the results of this study, the government of Bengkalis Regency can improve performance and maintain a fair audit opinion without the exception of the financial audit agency and classified into a clean and healthy government

Keywords: quality, competence, accounting, control, information technology.

(C)2018 FEB UNRAM. All rights reserved 


\section{DOI: $10.29303 /$ akurasi.v4i1.73}

Open access under Creative Commons Attribution-ShareAlike 4.0 International License.

(CC-BY-SA)

\section{Pendahuluan}

Pemerintah daerah sebagai lembaga dan pelayan publik harus bisa mengelola keuangan daerah secara profesional dalam rangka melahirkan pemerintahan yang bersih dan sehat sesuai dengan peraturan Menteri Dalam Negeri nomor 59 tahun 2007 (Kemendagri, 2007). Pemerintah daerah saat ini melakukan pengelolaan keuangan daerah memanfaatkan akuntansi sektor publik, dimana dapat digunakan sebagai perangkat penyediaan informasi baik bagi pemerintah itu sendiri maupun sebagai alat informasi bagi publik (Renyowijoyo, 2013). Salah satu bentuk informasi yang disajikan oleh pemerintah daerah terhadap publik adalah laporan keuangan. Dalam satu tahun anggaran, pemerintah daerah harus membuat laporan pertanggungjawaban atas pengelolaan keuangan daerah berupa laporan keuangan pemerintah daerah (LKPD) (Dariana \& Oktavia, 2018). LKPD akan berpengaruh dalam menilai kinerja pemerintah daerah.

Salah satu faktor terpenting dalam penyusunan LKPD adalah diperlukannya kompetensi staf akuntansi (KSA) yang baik, agar tercipta LKPD yang berkualitas baik (Hermansyah \& Marliana, 2019). Dalam menghasilkan LKPD yang efektif, efisien, transparan, tepat waktu, akuntabel dan berkualitas pemerintah daerah wajib menggunakan standar akuntansi pemerintah (SAP) yang terdapat pada peraturan pemerintah Republik Indonesia nomor 71 tahun 2010 (Presiden RI, 2010). Untuk menjaga kualitas LKPD perlu diterapkan sistem pengendalian internal (SPI) agar dapat meminimalisasi penyimpangan dan meningkatkan efisiensi dan efektifitas kinerja pemerintah daerah (Sihite \& Holiawati, 2017). Selain itu kualitas LKPD dapat ditingkatkan dengan pemanfaatan teknologi informasi (PTI), karena membuka akses bagi publik dalam mendapatkan dan menggunakan informasi keuangan secara cepat dan akurat (Hartawati \& Naim, 2020).

Studi yang menganalisis tentang determinan kualitas laporan keuangan pada pemerintah daerah telah dilakukan dalam banyak studi dengan hasil yang beragam. Nazrin, Rasuli, \& Safitri (2017); Sihite \& Holiawati (2017); Dariana \& Oktavia (2018); Hermansyah \& Marliana (2019) telah melakukan pengujian hubungan kompetensi staf akuntansi (KSA) dengan kualitas laporan keuangan (KLK). Studi tentang keterkaitan SAP dengan KLK telah pernah dilakukan oleh Sihite \& Holiawati (2017); Armel et al. (2017); Dariana \& Oktavia (2018); Jati (2019); Sholohah et al. (2019); Suprihatin \& Ananthy (2019); Hendri \& Erinos (2020); Yanti et al. (2020). Pengujian pengaruh determinan sistem pengendalian internal (SPI) terhadap kualitas laporan keuangan (KLK) telah dilakukan oleh Sihite \& Holiawati (2017); Armel et al. (2017); Dariana \& Oktavia (2018); Mulia (2019); Niliani (2019); AgustiningTyas et al. (2020); Firmansyah \& Sinambela (2020); Indrayani \& Widiastuti (2020); N. L. W. T. Lestari \& Dewi (2020). Berkaitan dengan pemanfaatan teknologi informasi dengan kualitas laporan keuangan (KLK) telah dilakukan riset empiris oleh Armel et al. (2017); Abdurrohman (2019); Mulyadita et al. (2019); Pravasanti \& Ningsih (2019); Tampubolon \& Hasibuan (2019). 
Setiap pemerintah daerah memiliki karakteristik dan faktor kontekstual yang berbeda termasuk kemampuan yang dimiliki sumberdaya manusia yang mengelola pelaporan keuangan maupun adaptasi terhadap perkembangan teknologi informasi. Dengan demikian studi ini ingin memberikan bukti baru dengan melakukan pengujian pada lokasi satuan organisasi pemerintah daerah yang berbeda, dalam hal ini pada Kabupaten Bengkalis, dengan menggunakan pengukuran variabel dan indikator dan alat pengujian yang berbeda. Hasil penelitian ini akan memberikan kontribusi dalam meningkatkan kualitas laporan keuangan pada satuan organisasi perangkat daerah di Kabupaten Bengkalis melalui penguatan faktor-faktor kunci yang relevan untuk menunjang peningkatan laporan keuangan pemerintah daerah yang berkualitas.

\section{Kerangka Teoretis Dan Pengembangan Hipotesis}

Kualitas laporan keuangan (KLK) merupakan parameter laporan akuntansi keuangan dalam memenuhi kebutuhan informasi pengguna atau pembaca laporan keuangan (Harahap, 2013). Untuk memenuhi kebutuhan pengguna, ukuran tujuan normatif perlu diwujudkan dalam laporan keuangan sehingga karakteristik KLK dapat dijelaskan dalam peraturan pemerintah Republik Indonesia nomor 71 Tahun 2010 (Pravasanti \& Ningsih, 2019; Presiden RI, 2010). Karakteristik kualitas yang dibutuhkan dalam LKPD adalah relevan, andal, dapat dibandingkan dan dapat dipahami (Pravasanti \& Ningsih, 2019). KLK yang baik menurut akuntan publik bisa dilihat dari pemberian opini wajar tanpa pengecualian (WTP) dari pihak auditor (Emay et al., 2019). Hasil telaah studi sebelumnya telah menguji kualitas staf akuntansi (KSA), Standar Akuntansi Pemerintahan (SAP), Sistem Pengendalian Intern (SPI) dan Pemanfaatan Teknologi Informasi (PTI) sebagai faktor-faktor yang mempengaruhi kualitas laporan keuangan pemerintah daerah dengan temuan penelitian menunjukkan hasil yang beragam.

Kompetensi merupakan karakteristik dan kapabilitas kerja yang terdiri dari unsur pengetahuan, keterampilan, dan sikap dalam melaksanakan tugas (BKN, 2013). Pengetahuan merupakan informasi yang dipunyai oleh seseorang ketika mengerjakan tugas dan tanggung jawabnya, keterampilan merupakan upaya seseorang ketika mengerjakan tugas dan tanggung jawabnya, sedangkan sikap adalah gambaran tingkah laku seseorang ketika mengerjakan tugas dan tanggung jawabnya (Lestari, 2020). Kualitas sumber daya manusia dari staf akuntansi (KSA) merupakan aspek-aspek pribadi yang dipunyai oleh seorang staf akuntansi dalam mencapai suatu kinerja, dimana staf akuntansi harus memiliki lima keterampilan dalam melaksanakan pekerjaannya (Emay, Fajar, \& Suparwo, 2019). Studi yang berbeda mengemukakan bahwa kualitas staf akuntansi (KSA) atau kualitas SDM (KSDM) memiliki pengaruh terhadap KLK dilakukan oleh Nazrin et al. (2017), Sihite \& Holiawati (2017), Armel et al. (2017), Dariana \& Oktavia (2018) dan Gasperz (2019). Hasil yang sejalan ditemukan dalam studi Abdurrohman (2019), Hermansyah \& Marliana (2019), Tampubolon \& Hasibuan (2019), Tangko et al. (2019), Apriansyah et al. (2020), Hartono \& Ramdany (2020), Hendri \& Erinos (2020), Lestari (2020) dan Sikumbang et al. (2020). Kontradiktif dengan temuan sebelumnya, studi Emay et al. (2019), AgustiningTyas et al. (2020) dan Philadhelphia et al. (2020) menemukan hasil bahwa KSA atau KSDM tidak berpengaruh terhadap KLK. Laporan keuangan pemerintah yang berkualitas dapat dihasilkan oleh tenaga akuntansi yang berkualitas dan kompeten, 
sehingga ketika kompetensi staf akuntansi semakin baik maka diprediksi akan berdampak terhadap peningkatan kualitas laporan keuangan pemerintah daerah. Dengan demikian diajukan hipotesis sebagai berikut:

$\mathrm{H}_{1}$ : Kompetensi staf akuntansi berpengaruh signifikan terhadap kualitas laporan keuangan

pemerintah daerah.

Standar akuntansi merupakan panduan dan dasar-dasar dalam mengatur pelaksanaan akuntansi ketika menyusun laporan keuangan. Standar akuntansi merupakan hal yang dibutuhkan dalam mencapai konsistensi pelaporan keuangan (Halim \& Khusufi, 2013). Standar Akuntansi Pemerintahan (SAP) merupakan urutan mekanisme, pelaksana, perangkat, dan elemen lain yang sistematik dalam merealisasikan peran akuntansi mulai dari analisis transaksi hingga pelaporan keuangan di lingkungan pemerintah (Presiden RI, 2010). Komponen pernyataan SAP berbasis kas menuju akrual terdiri dari dua belas lampiran (Hendri \& Erinos, 2020; Presiden RI, 2010). Keberadaan SAP akan bermanfaat dalam penyusunan laporan keuangan yang akan disajikan kepada publik (Yanti et al., 2020). Beberapa studi empiris menemukan pengaruh signifikan dari Standar Akuntansi Pemerintahan terhadap KLK sebagaimana telah dilakukan dalam beberapa studi yang relevan (Armel et al., 2017; Sihite \& Holiawati,2017; Dariana \& Oktavia, 2018; Dwiyana et al., 2019; Jati, 2019; Suprihatin \& Ananthy, 2019). Temuan yang sejalan diperoleh dari penelitian Tangko et al. (2019), Hartono \& Ramdany (2020), Hendri \& Erinos (2020), Philadhelphia et al. (2020), Rohmah et al. (2020), Taviana \& Riharjo (2020) dan Yanti et al. (2020). Namun demikian hasil berbeda ditemukan dalam studi Sholohah et al. (2019); Apriansyah et al. (2020) dengan hasil yang tidak signifikan dalam hubungan SAP terhadap KLK. Penelitian ini memprediksi bahwa ketentuan dalam SAP akan menjadi pedoman dalam penyusunan laporan keuangan sehingga dapat menghasilkan laporan keuangan pemerintah daerah yang berkualitas. Dengan demikian dapat dirumuskan hipotesis sebagai berikut:

$\mathrm{H}_{2}$ : Standar Akuntansi Pemerintahan (SAP) berpengaruh signifikan terhadap kualitas laporan keuangan pemerintah daerah.

Faktor lain yang mendukung terciptanya kualitas laporan keuangan pemerintah daaerah adalah Sistem Pengendalian Internal (SPI). SPI merupakan mekanisme keseluruhan dari aksi dan aktivitas yang dilaksanakan secara kontinu oleh manajemen dalam meyakinkan terciptanya tujuan organisasi lewat aktivitas yang efektif dan efisien, keunggulan laporan keuangan, perlindungan aset negara, dan kepatuhan terhadap peraturan (Presiden RI, 2008; Putri \& Hendarsyah, 2020). SPI terdiri dari format organisasi, prosedur, dan bentuk-bentuk yang diatur dalam menjaga kekayaan organisasi, memastikan akurasi dan kualitas data akuntansi, meningkatkan efisiensi serta menstimulasi ketaatan atas kebijakan manajemen (Mulyadi, 2010). SPI menjelaskan tentang lima komponen atau unsur yang harus diterapkan dalam kegiatan roda pemerintahan (Noviani \& Hendarsyah, 2020; Presiden RI, 2008) yang meliputi lingkungan pengendalian, penilaian risiko, aktivitas pengendalian, informasi dan komunikasi serta pemantauan. Hasil penelitian sebelumnya mengungkap adanya pengaruh signifikan penerapan SPI terhadap kualitas laporan keuangan pemerintah daerah sebagaimana dinyatakan dalam penelitian Armel et 
al. (2017), Sihite \& Holiawati (2017), Dariana \& Oktavia (2018), Dwiyana et al. (2019), Emay et al. (2019), Gasperz (2019), Mulia (2019) dan Niliani (2019). Hasil yang relevan juga ditemukan dalam studi lainnya (AgustiningTyas et al., 2020, Firmansyah \& Sinambela, 2020, Hartono \& Ramdany, 2020, Indrayani \& Widiastuti, 2020; Lestari 2020; Lestari \& Dewi, 2020; Rohmah et al., 2020; Sikumbang et al., 2020). Namun demikian hasil penelitian Hartawati \& Naim (2020); Philadhelphia et al. (2020) menunjukkan temuan yang kontradiktif bahwa SPI tidak berpengaruh terhadap kualitas laporan keuangan pemerintah daerah. Efektivitas impementasi SPI pada pemerintah daerah diprediksi akan meningkatkan kualitas laporan keuangan pemerintah daerah sehingga diajukan hipotesis sebagai berikut:

$\mathrm{H}_{3}$ : Sistem Pengendalian Intern berpengaruh signifikan terhadap kualitas laporan keuangan pemerintah daerah

Teknologi informasi merupakan teknologi yang dimanfaatkan dalam kegiatan pengolahan data. Kegiatan tersebut termasuk didalamnya mendapatkan, memasukkan, memproses, menata, mengarsipkan, dan memanipulasi data dalam menciptakan suatu informasi yang berkualitas (Uno \& Lamatenggo, 2011). Teknologi informasi dapat juga dikatakan sebagai pengetahuan di bidang informasi yang berbasis komputerisasi, dimana kemajuannya berkembang dengan pesat (Lantip \& Riyanto, 2011). Pemanfaatan Teknologi Informasi (PTI) dapat diukur melalui penggunaan hardware, software dan brainware serta jaringan dan komunikasi (Pravasanti \& Ningsih, 2019). Pengembangan dan pemanfaatan IT wajib dilaksanakan oleh pemerintah pusat dan daerah ketika melakukan kegiatan pengelolaan keuangan serta menyajikan informasi keuangan kepada publik (Presiden RI, 2005). Hasil penelitian sebelumnya menyatakan bahwa pemanfaatan Teknologi Informasi (PTI) berpengaruh terhadap kualitas laporan keuangan sebagaimana dinyatakan dalam studi Armel et al. (2017), Abdurrohman (2019), Mulyadita et al. (2019), Pravasanti \& Ningsih (2019), Tangko et al. (2019), Hartawati \& Naim (2020), Sikumbang et al. (2020), Taviana \& Riharjo (2020). Kontradiktif dengan temuan penelitian sebelumnya, hasil penelitian yang dilakukan oleh Gasperz (2019), Tampubolon \& Hasibuan (2019), Apriansyah et al. (2020) menemukan pengaruh tidak signifikan pemanfaatan teknologi informasi dalam menghasilkan laporan keuangan pemerintah daerah yang berkualitas. Penelitian ini mengargumentasikan bahwa optimalisasi pemanfaatan teknologi informasi dalam proses pelaporan keuangan akan meningkatkan kualitas laporan keuangan pemerintah daerah. Dengan demikian dapat diajukan hipotesis sebagai berikut:

$\mathrm{H}_{4}$ : Pemanfaatan Teknologi Informasi berpengaruh signifikan terhadap kualitas laporan keuangan pemerintah daerah

\section{Metode Penelitian}

Studi ini dilaksanakan pada pemerintah daerah Kabupaten Bengkalis yang terdiri dari 34 satuan organisasi perangkat daerah (SOPD). Populasi dari studi ini adalah pegawai yang bekerja pada sub bagian keuangan dan perlengkapan seluruh SOPD Kabupaten Bengkalis. Penggunaan sampel dalam studi ini menggunakan metode proportional sampling, yang bertujuan agar dapat memperhatikan proporsi unsur-unsur atau kategori dalam populasi pada studi ini. Dasar pengambilan sampel pada studi ini terdiri 5 orang 
masing-masing SOPD yaitu terdiri dari kepala sub bagian keuangan dan perlengkapan, bendahara pengeluaran, bendahara penerimaan, staf keuangan dan tenaga akuntansi pemerintah daerah Kabupaten Bengkalis. Total sampel pada studi ini awalnya 170 orang, tetapi setelah dilakukan pengumpulan kuesioner yang kembali hanya sebanyak 153 . Dengan demikian total sampel pada studi ini sebanyak 153 orang dari 34 SOPD Kabupten Bengkalis, dengan rincian kepala sub bagian keuangan dan perlengkapan sebanyak 34 orang, bendahara pengeluaran 34 orang, bendahara penerimaan 17 orang, staf keuangan 34 orang, tenaga akuntansi 34 orang. Studi ini dirancang menggunakan metode deskriptif kuantitatif dengan sumber data primer dan sekunder, dimana data dihimpun melalui kuesioner dan studi pustaka. Data yang dikumpulkan kemudian dianalisis menggunakan analisis regresi linear berganda dengan terlebih dahulu melakukan pengujian validitas dan reliabilitas serta uji normalitas data.

\section{Hasil dan Pembahasan}

Berdasarkan hasil kuesioner yang diterima dari masing-masing SOPD Kabupaten Bengkalis, didapat data responden sebanyak 153 orang. Data tersebut dikelompokkan menurut jenis kelamin, umur, tingkat pendidikan dan masa kerja. Berdasarkan jenis kelamin, laki-laki 68 orang $(44,4 \%)$ dan perempuan 85 orang $(55,6 \%)$. Berdasarkan umur, 20 - 25 tahun 15 orang $(9,8 \%), 26-30$ tahun 35 orang (23\%), 31-35 tahun 36 orang $(23,5 \%)$, $36-40$ tahun 37 orang $(24,1 \%)$, lebih dari 40 tahun sebanyak 30 orang $(19,6 \%)$ sehingga responden adalah staf akuntansi pada usia kerja produktif. Berdasarkan tingkat pendidikan, jumlah responden yang berijazah SLTA Sederajat sebanyak 25 orang (16,3\%), Diploma III 28 orang (18,3\%), Diploma IV 35 orang (23\%), S1 50 orang (32,6\%), S2 15 orang $(9,8 \%)$. Kemudian berdasarkan masa kerja, 1-5 tahun 65 orang $(42,4 \%)$, 6-10 tahun 59 orang $(38,5 \%)$ dan lebih dari 10 tahun sebanyak 29 orang $(18,6 \%)$ yang menunjukkan bahwa mayoritas responden adalah orang yang memiliki pengalaman kerja cukup.

Pengujian validitas data berguna untuk menakar valid atau tidaknya suatu kuesioner (Siregar, 2013). Berdasarkan data kuesioner didapat nilai $\alpha$ sebesar 0,05, n sebesar 153; df $=(\mathrm{n}-2)=153-2=151$, jika dilihat nilai $\mathrm{r}_{\text {tabel }}$ pada tabel $\mathrm{r}$ maka didapat nilai $\mathrm{r}_{\text {tabel }}$ sebesar 0,1587. Keputusan validitas, jika rhitung $>$ rtabel maka validitas data valid, selain itu tidak valid (Siregar, 2013). Hasil output pengolahan data menunjukkan bahwa rhitung terendah yaitu 0,460 dan rhitung tertinggi 0,906, jika dibandingkan dengan $\mathrm{r}_{\text {tabel }}$ maka keseluruhan rhitung $>0,1587$, sehingga bisa dikatakan data kuesioner valid. Hasil pengujian validitas data telah memenuhi reliabilitas. Instrumen penelitian reliabel, jika cronbach's alpha > 0,60 (Siregar, 2013). Berdasarkan olahan data kuesioner didapat nilai cronbach's alpha sebagimana disajikan pada Tabel 1, nilai cronbach's alpha masing-masing variabel lebih besar dari 0,60 , sehingga data kuesioner reliabel.

Tabel 1. Hasil Uji Reliabitas

\begin{tabular}{cc}
\hline Variabel & Cronbach's Alpha \\
\hline KSA & 0,768 \\
SAP & 0,859 \\
SPI & 0,717 \\
PTI & 0,860 \\
KLK & 0,734 \\
\hline
\end{tabular}

Sumber: Data Penelitian (diolah) 
Hasil uji normalitas menunjukkan bahwa data terdistribusi normal. Normalitas data dapat diuji dengan menggunakan pengujian kolmogorov-smirnov. Apabila nilai Asymp. Sig. pada pengujian $>0,05$ maka data terdistribusi normal, sebaliknya tidak normal (Yusuf, 2014). Dari hasil pengujian kolmogorov-smirnov didapat nilai Asymp. Sig. sebesar 0,251. Artinya $0,251>0,05$, sehingga dapat dinyatakan data kuesioner terdistribusi normal.

Hasil pengujian kelayakan model dan koefisien determinasi serta uji signifikansi hipotesis disajikan pada Tabel 2. Kelayakan model diuji dievaluasi berdasarkan nilai signifikansi secara simultan yang ditunjukkan dengan nilai $\mathrm{f}_{\text {tabel, }}$, dimana nilai df1 $=\mathrm{k}-1=$ $5-1=4 ;$ df $2=n-k=153-5=148, \alpha=0,05$, jika dilihat pada tabel $\mathrm{f}$ maka didapat $\mathrm{f}_{\text {tabel }}=$ 2,430 . Nilai $f_{\text {hitung }}=142,889$ dan signifikansi $=0,000$, berarti nilai $f_{\text {hitung }}>f_{\text {tabel }}(142,889>$ $2,430)$ dan nilai signifikansi lebih kecil dari $0,05(0,000<0,05)$. Dengan demikian dapat dinyatakan bahwa model layak untuk digunakan sebagai model prediksi. Koefisien determinasi ditunjukkan oleh nilai Adjusted $R$ Square $=0,789$ atau $=78,9 \%$, sehingga kemampuan variabel KSA, SAP, SPI dan PTI dalam memprediksi kualitas laporan keuangan adalah sebesar 78,9\% dan sisanya sebesar 21,1 dipengaruhi oleh variabel lain di luar model yang dispesifikasikan.

Tabel 2. Hasil Uji Hipotesis

\begin{tabular}{llcc}
\hline & \multicolumn{1}{c}{ Hipotesis } & $\mathrm{t} / \mathrm{f}$ & Sig. \\
\hline $\mathrm{H} 1$ & KSA $\rightarrow$ KLK & 17,149 & 0,000 \\
$\mathrm{H} 2$ & SAP $\rightarrow$ KLK & 22,967 & 0,000 \\
$\mathrm{H} 3$ & SPI $\rightarrow$ KLK & 7,700 & 0,000 \\
$\mathrm{H} 4$ & PTI $\rightarrow$ KLK & 6,648 & 0,000 \\
\hline$R$ & 0,891 & \\
$R$ Square & 0,794 & \\
Adjusted $R$ Square & 0,789 & \\
\hline \multicolumn{2}{l}{ Sumber: Data primer (diolah) }
\end{tabular}

Pengujian hipotesis secara parsial diperlukan nilai tabel, dimana nilai $\mathrm{n}=153 ; \mathrm{k}=5$; $\alpha / 2=0,05 / 2=0,025 ; \mathrm{df}=\mathrm{n}-\mathrm{k}=153-5=148$, jika dilihat pada tabel $\mathrm{t}$ didapat nilai tabel $=$ 1,976. Keputusan uji parsial dapat diambil jika thitung $>t_{\text {tabel }}$ atau sig. $<0,05$ maka hipotesis diterima, dan jika sebaliknya ditolak (Yusuf, 2014). Hasil pengujian hipotesis berdasarkan Tabel 2 dapat diketahui semua hipotesis memiliki nilai signifikansi lebih kecil dari 5\% dan nilai $\mathrm{t}$ hitung lebih besar dari $\mathrm{t}$ tabel 1,976. Hasil pengujian hipotesis pertama menunjukkan pengaruh variabel KSA terhadap KLK mempunyai nilai thitung $=17,149$ dan sig. $=0,000$, berarti nilai thitung $>$ tabel $(17,149>1,976)$ dan nilai sig. $<0,05(0,000<0,05)$ sehingga hipotesis pertama $\left(\mathrm{H}_{1}\right)$ diterima. Pengaruh variabel SAP terhadap KLK memiliki nilai $t_{\text {hitung }}=22,967$ dan sig. $=0,000$, berarti nilai thitung $>t_{\text {tabel }}(22,967>1,976)$ dan nilai sig. $<0,05(0,000<0,05)$ sehingga hipotesis kedua $\left(\mathrm{H}_{2}\right)$ diterima. Selanjutnya pengaruh variabel SPI terhadap KLK mempunyai nilai thitung $=7,700$ dan sig. $=0,000$, berarti nilai $t_{\text {thitung }}>$ t tabel $_{(7,700>1,976)}$ dan nilai sig. $<0,05(0,000<0,05)$ sehingga hipotesis ketiga $\left(\mathrm{H}_{3}\right)$ dapat didukung. Hasil yang konsisten ditemukan dalam pengujian hipotesis keempat $\left(\mathrm{H}_{4}\right)$ tentang pengaruh PTI terhadap KLK dalam penelitian ini dapat diterima, yang ditunjukkan oleh thitung $=6,648$ dan sig. $=0,000$, berarti nilai thitung $>$ tabel $(6,648>1,976)$ dan nilai sig. $<0,05(0,000<0,05)$. 
Hasil penelitian ini mendukung hipotesis pertama yang menyatakan adanya pengaruh signifikan positif kompetensi staf akuntansi (KSA) terhadap kualitas laporan keuangan (KLK) pada pemerintah daerah. Hal tersebut mengisyaratkan bahwa dalam penyusunan laporan keuangan, kompetensi staf dibidang akuntansi merupakan aspek yang sangat penting. Hal ini dikarenakan apabila staf mempunyai pengetahuan dan keterampilan akuntansi yang mumpuni serta sikap yang baik, maka seharusnya dapat membuat laporan keuangan yang berkualitas dan hasilnya dapat dipertanggungjawabkan. Sebaliknya apabila staf akuntansi tidak mempunyai pengetahuan dan keterampilan akuntansi yang mumpuni serta sikap yang baik, maka laporan keuangan diragukan kualitasnya dan hasilnya tidak dapat dipertangggungjawabkan. Dalam hal ini pemerintah daerah Kabupaten Bengkalis telah menetapkan kompentensi bagi staf akuntansi pada setiap SOPD yang ada, sehingga dapat menyajikan laporan keuangan yang berkualitas. Hasil penelitian ini sejalan dengan temuan studi studi Armel et al. (2017), Nazrin et al. (2017), Sihite \& Holiawati (2017), Dariana \& Oktavia (2018), Gasperz (2019), Abdurrohman (2019), Hermansyah \& Marliana (2019) serta Tampubolon \& Hasibuan (2019). Hasil penelitian ini juga mendukung studi Tangko et al. (2019), Apriansyah et al. (2020), Hartono \& Ramdany (2020), Hendri \& Erinos (2020), Lestari (2020) dan Sikumbang et al. (2020) yang menyatakan bahwa kualitas laporan keuangan pemerintah daerah dipengaruhi secara signifikan oleh kualitas staf akuntansi. Namun demikian hasil penelitian ini kontradiktif dengan temuan studi Emay et al. (2019), AgustiningTyas et al. (2020) dan Philadhelphia et al. (2020) yang menyatakan bahwa kompetensi staf akuntansi atau kualitas sumberdaya manuasia yang memproses laporan keuangan tidak signifikan dalam mempengaruhi kualitas laporan keuangan pemerintah daerah.

Temuan penelitian ini juga mendukung hipotesis kedua yang menemukan hasil bahwa adanya Standar Akuntansi Pemerintahan (SAP) yang diimplementasikan semakin baik dapat meningkatkan kualitas laporan keuangan pemerintah daerah. Hal tersebut mengindikasikan bahwa SAP daerah Kabupaten Bengkalis telah menggunakan asas akuntansi yang telah dikukuhkan dalam kegiatan penyusunan dan penyajian laporan keuangan pemerintah. Kemudian SAP menjamin laporan keuangan yang disajikan telah memenuhi kualitas informasi keuangan yang bermanfaat untuk publik. Dalam hal ini pemerintah daerah Kabupaten Bengkalis telah menggunakan standar akuntansi yang sesuai dengan peraturan pemerintah Republik Indonesia nomor 71 tahun 2010. Dengan demikian laporan keuangan pemerintah daerah (LKPD) Kabupaten Bengkalis memenuhi karakteristik kualitas dan mendapatkan opini audit WTP dari Badan Pemeriksa Keuangan (BPK). Hasil ini sejalan dengan studi Armel et al. (2017), Sihite \& Holiawati (2017), Dariana \& Oktavia (2018), Dwiyana et al. (2019), Jati (2019), Suprihatin \& Ananthy (2019) serta Tangko et al. (2019). Hasil penelitian ini juga mendukung hasil studi Hartono \& Ramdany (2020), Hendri \& Erinos (2020), Philadhelphia et al. (2020), Rohmah et al. (2020), Taviana \& Riharjo (2020) dan Yanti et al. (2020) yang menyatakan adanya pengaruh signifikan SAP terhadap KLK. Namun demikian hasil ini tidak mendukung studi Sholohah et al. (2019) dan Apriansyah et al. (2020) yang menyatakan bahwa SAP tidak berpengaruh terhadap KLK.

Hasil penelitian ini mendukung hipotesis ketiga yang mengungkapkan bahwa penerapan SPI yang efektif memiliki pengaruh yang signifikan terhadap peningkatan 
kualitas laporan keuangan pemerintah daerah Kabupaten Bengkalis. Hal ini mengisyaratkan bahwa SPI sangat penting dalam mengontrol kegiatan pemerintahan di setiap satuan organisasi pemerintah daerah (SOPD) yang ada. Tujuannya adalah untuk memastikan terlaksananya kerja pemerintah dan mencegah sesuatu yang dapat merugikan negara. Oleh sebab itu pemerintah daerah Kabupaten Bengkalis telah menerapkan komponen-komponen SPI yang sesuai dengan peraturan pemerintah Republik Indonesia nomor 60 tahun 2008 sehingga laporan keuangan yang berkualitas tercipta. Temuan ini sejalan dengan studi bahwa kualitas laporan keuangan pemerintah daerah secara signifikan dipengaruhi oleh efektivitas SPI, sebagaimana dinyatakan dalam penelitian Armel et al. (2017), Sihite \& Holiawati (2017), Dariana \& Oktavia (2018), Dwiyana et al. (2019), Emay et al. (2019), Gasperz (2019), Mulia (2019) dan Niliani (2019). Hasil penelitian ini juga mendukung studi AgustiningTyas et al. (2020), Firmansyah \& Sinambela (2020), Hartono \& Ramdany (2020), Indrayani \& Widiastuti (2020), Lestari (2020); Lestari \& Dewi (2020), Rohmah et al. (2020) dan Sikumbang et al. (2020). Namun demikian, hasil ini tidak sejalan dengan temuan studi yang dilakukan oleh Hartawati \& Naim (2020); Philadhelphia et al. (2020) yang menyatakan bahwa SPI tidak berpengaruh terhadap KLK.

Hasil studi ini mendukung hipotesis keempat yang menyatakan bahwa pemanfaaatan teknologi informasi (PTI) berpengaruh signifikan terhadap kualitas laporan keuangan pada pemerintah daerah Kabupaten Bengkalis. Hal tersebut mengindikasikan bahwa PTI dapat meningkatkan kemampuan dalam mengelola keuangan daerah sehingga menghasilkan KLK yang baik serta dapat menciptakan transparansi dan akuntabilitas keuangan daerah. Oleh karena itu, pemerintah daerah Kabupaten Bengkalis sudah melaksanakannya sesuai dengan peraturan pemerintah Republik Indonesia nomor 56 tahun 2005 sehingga menghasilkan laporan keuangan yang akurat dan berkualitas. Hasil ini sejalan dengan studi Armel et al. (2017), Abdurrohman (2019), Mulyadita et al. (2019), Tangko et al. (2019), Pravasanti \& Ningsih (2019), Hartawati \& Naim (2020), Sikumbang et al. (2020) serta Taviana \& Riharjo (2020) yang menyatakan bahwa PTI berpengaruh terhadap KLK. Namun demikian, temuan ini bertolak belakang dengan studi Gasperz (2019), Tampubolon \& Hasibuan (2019), Apriansyah et al. (2020) yang menyatakan bahwa PTI tidak berpengaruh terhadap kualitas laporan keuangan pemerintah daerah.

\section{Kesimpulan, Implikasi dan Keterbatasan}

Hasil penelitian ini mengungkapkan bahwa kualitas laporan keuangan pemerintah daerah dipengaruhi secara signifikan oleh kompetensi staf akuntansi, Standar Akuntansi Pemerintahan (SAP), penerapan SPI dan pemanfaatan teknologi informasi. Hasil penelitian ini menunjukkan pentingnya penguatan faktor-faktor internal organisasi seperti sumberdaya daya manusia dan optimalisasi pemanfaatan teknologi informasi serta kepatuhan penerapan regulasi serta pemantauan pelaksanaan pengendalian internal yang efektif dalam menunjang kinerja pemerintah daerah. Temuan ini mengindikasikan bahwa melalui laporan keuangan pemerintah daerah yang berkualitas maka pemerintah daerah Kabupaten Bengkalis dapat meningkatkan kinerja dan mempertahankan opini audit WTP dari BPK dan tergolong ke dalam pemerintah yang bersih dan sehat. Studi ini memiliki keterbatasan, oleh sebab itu diharapkan studi selanjutnya supaya dapat meneliti faktorfaktor internal dan eksternal organisasi selain KSA, SAP, SPI dan PTI, yang dapat 
mendorong peningkatan laporan keuangan pemerintah daerah sehingga dapat mempertahankan kualitas laporan keuangan pada pemerintah daerah (LKPD) dengan opini audit WTP dimasa yang akan datang.

\section{Daftar Pustaka}

Abdurrohman, H. (2019). Pengaruh Kompetensi Pengaruh Kompetensi Sumber Daya Manusia dan Pemanfaatan Teknologi Informasi Terhadap Kualitas Laporan Keuangan Pemerintah Daerah (Studi pada Badan Pengelolaan Keuangan dan Aset Daerah (BPKAD) Kabupaten Sumbawa). Journal of Accounting, Finance, and Auditing, 1(2). https://doi.org/10.37673/jafa.v1i2.306

AgustiningTyas, V. E., Tyasari, I., \& Yogivaria, D. W. (2020). Pengaruh Good Governance, Sistem Pengendalian Intern Pemerintah, Kompetensi Sumber Daya Manusia Terhadap Kualitas Laporan Keuangan Pemerintah Daerah (LKPD) Pada OPD Kota Malang. Jurnal Riset Mahasiswa Akuntansi, 8(1), 1-14. https://doi.org/10.21067/jrma.v8i1.4458

Apriansyah, H., Rahayu, S., \& Erwati, M. (2020). Pengaruh Penerapan Standar Akuntansi Pemerintahan, Kompetensi Sumber Daya Manusia dan Pemanfaatan Teknologi Informasi Terhadap Kualitas Laporan Keuangan Pemerintahan Daerah Kabupaten Bungo. JAR: Jambi Accounting Review, 1(1), 44-62. Retrieved from https://onlinejournal.unja.ac.id/JAR/article/view/10944

Armel, R. Y. G., Nasir, A., \& Safitri, D. (2017). Pengaruh Kompetensi Sumber Daya Manusia, Penerapan Standar Akuntansi Pemerintahan, Pemanfaatan Teknologi Informasi dan Sistem Pengendalian Internal terhadap Kualitas Laporan Keuangan Pemerintah Daerah (Studi pada Satuan Kerja Perangkat Daerah Kota Dumai). Jurnal Online Mahasiswa Fakultas Ekonomi UNRI, 4(1), 105-119. Retrieved from https://jom.unri.ac.id/index.php/JOMFEKON/article/view/12059

BKN. (2013). Peraturan Kepala Badan Kepegawaian Negara Nomor 7 Tahun 2013 Tentang Pedoman Penyusunan Standar Kompetensi Manajerial Pegawai Negeri Sipil. Retrieved from https://www.bkn.go.id/wp-content/uploads/2015/10/.pdf

Dariana, D., \& Oktavia, J. (2018). Pengaruh Penerapan Standar Akuntansi Pemerintahan, Sistem Pengendalian Internal, Dan Kompetensi Staf Akuntansi Terhadap Kualitas Laporan Keuangan. JAS (Jurnal Akuntansi Syariah), 2(1), 77-105. Retrieved from https://ejournal.stiesyariahbengkalis.ac.id/index.php/jas/article/view/132

Dwiyana, I. M. A., Yudantara, I. G. A. P., \& Julianto, I. P. (2019). Implementasi Standar Akuntansi Pemerintah (SAP), Sistem Pengendalian Intern Pemerintah (SPIP) Dan Peran Internal Audit Inspektorat Daerah Terhadap Kualitas Laporan Keuangan Satuan Kerja Perangkat Daerah. Jurnal Akuntansi Profesi, 10(2), 45-53. Retrieved from https://ejournal.undiksha.ac.id/index.php/JAP/article/view/22865

Emay, E., Fajar, C. M., \& Suparwo, A. (2019). Dampak Audit Internal, Pengendalian 
Internal, Dan Kompetensi Staf Akuntansi Terhadap Kualitas Laporan Keuangan. Jurnal Ecodemica: Jurnal Ekonomi, Manajemen, Dan Bisnis, 3(1), 36-44. Retrieved from https://ejournal.bsi.ac.id/ejurnal/index.php/ecodemica/article/view/4442

Firmansyah, I., \& Sinambela, R. T. (2020). Pengaruh Sistem Pengendalian Internal Terhadap Kualitas Laporan Keuangan Pada Badan Pengelolaan Keuangan Dan Aset Daerah Provinsi Jawa Barat. LAND JOURNAL: Logistic And Accounting Development Journal, 1(1), 1-15. Retrieved from https://ejurnal.poltekpos.ac.id/index.php/jurnalland/article/view/557

Gasperz, J. (2019). Pengaruh Kompetensi Sumber Daya Manusia, Sistem Pengendalian Intern, dan Pemanfaatan Teknologi Informasi terhadap Kualitas Laporan Keuangan (Studi pada Badan Pusat Statistik Wilayah Maluku). JBMP (Jurnal Bisnis, Manajemen Dan Perbankan), 5(2), 75-83. https://doi.org/10.21070/jbmp.v5i2.2550

Halim, A., \& Khusufi, M. S. (2013). Akuntansi Sektor Publik, Akuntansi Keuangan Daerah. Jakarta: Salemba Empat.

Harahap, S. S. (2013). Analisa Kritis atas Laporan Keuangan. Jakarta: PT. Raja Grafindo Persada.

Hartawati, S. I., \& Naim, M. R. (2020). Implementasi Pemanfaatan Teknologi Informasi dan Pengendalian Intern terhadap Kualitas Laporan Keuangan. Jurnal Economic Resources, 2(2), 139-146. https://doi.org/10.33096/jer.v2i2.397

Hartono, H., \& Ramdany, R. (2020). Pengaruh Penerapan Standar Akuntansi Pemerintahan, Efektivitas Sistem Pengendalian Intern Dan Kompetensi Sumber Daya Manusia Terhadap Kualitas Laporan Keuangan. Jurnal Akuntansi, 9(1), 14-23. Retrieved from http://ejournal.stiemj.ac.id/index.php/akuntansi/article/view/90

Hendri, M., \& Erinos, N. R. (2020). Pengaruh Kualitas Sumber Daya Manusia, Implementasi Sistem Informasi Manajemen Daerah Dan Penerapan Standar Akuntansi Pemerintah Terhadap Kualitas Laporan Keuangan Pemerintah Daerah (Studi Empiris Pada OPD Provinsi Sumatera Barat). JEA: Jurnal Eksplorasi Akuntansi, 2(1), 2479-2493. from http://jea.ppj.unp.ac.id/index.php/jea/article/view/224

Hermansyah, I., \& Marliana, R. (2019). Peran Kompetensi Staf Akuntansi Dalam Pencapaian Kualitas Informasi Keuangan Daerah (Sensus Pada Kantor Kecamatan Kota Tasikmalaya). Jurnal Akuntansi, 14(2), 60-66. Retrieved from http://jurnal.unsil.ac.id/index.php/jak/article/view/1232

Indrayani, K. D., \& Widiastuti, H. (2020). Pengaruh Penerapan Sistem Akuntansi Keuangan Pemerintah Daerah dan Sistem Pengendalian Internal Terhadap Kualitas Laporan Keuangan Pemerintah Daerah Dengan Kompetensi Sumber Daya Manusia Sebagai Variabel Moderasi (Studi Empiris Pada Satuan Kerja Perangkat. Reviu Akuntansi Dan Bisnis Indonesia, 4(1), 1-16. https://doi.org/10.18196/rab.040148

Jati, B. P. (2019). Pengaruh Penerapan Standar Akuntansi Pemerintahan Berbasis Akrual 
Terhadap Kualitas Laporan Keuangan Pemerintah Daerah. Wahana: Jurnal Ekonomi, Manajemen Dan Akuntansi, 22(1), 1-14. https://doi.org/10.35591/wahana.v22i1.145

Kemendagri. (2007). Peraturan Menteri Dalam Negeri Nomor 59 Tahun 2007 Tentang Perubahan Atas Peraturan Menteri Dalam Negeri Nomor 13 Tahun 2006 Tentang Pedoman Pengelolaan Keuangan Daerah. Retrieved from https://peraturan.bpk.go.id/Home/Download/117460/Permen No.59-2007.pdf

Lantip, P. D., \& Riyanto. (2011). Teknologi Informasi Pendidikan. Yogyakarta: Gava Media.

Lestari, F. A. P. (2020). Pengaruh Sistem Akuntansi, Kompetensi Staf Akuntansi dan Internal Control Terhadap Kualitas Laporan Keuangan Perusahaan. Sosio E-Kons, 12(1), 60-69. https://doi.org/10.30998/sosioekons.v12i1.5630

Lestari, N. L. W. T., \& Dewi, N. N. S. R. T. (2020). Pengaruh Pemahaman Akuntansi, Pemanfaatan Sistem Informasi Akuntansi Dan Sistem Pengendalian Intern Terhadap Kualitas Laporan Keuangan. KRISNA: Kumpulan Riset Akuntansi, 11(2), 170-178. https://doi.org/10.22225/kr.11.2.1435.170-178

Mulia, R. A. (2019). Analisis Faktor-Faktor Yang Mempengaruhi Kualitas Laporan Keuangan Pemerintah Daerah (Studi Pada Pemerintah Kabupaten Pasaman Barat). Jurnal EL-RIYASAH, 9(1), 7-21. https://doi.org/10.24014/jel.v9i1.6798

Mulyadi. (2010). Sistem Akuntansi, Edisi ke-3, Cetakan ke-5. Jakarta: Salemba Empat.

Mulyadita, R., Ratnawati, V., \& Silfi, A. (2019). Pengaruh Kapasitas Sumber Daya Manusia, Pemanfaatan Teknologi, Pengelolaan Aset terhadap Kualitas Laporan Keuangan Pemerintah Daerah dengan Sistem Pengendalian Intern dan Komitmen Organisasi sebagai Variabel Moderating (Studi pada OPD Kabupaten Rokan Hili. Jurnal Ekonomi, 27(1), 82-91. https://doi.org/10.31258/je.27.1.p.82-91

Nazrin, P. M., Rasuli, M., \& Safitri, D. (2017). Pengaruh Kompetensi Staf Akuntansi, Penerapan Sistem Akuntansi Keuangan dan Pengelolaan Keuangan Daerah terhadap Kualitas Laporan Keuangan Pemerintah Daerah (Studi pada SKPD Kota Bukittinggi). Jurnal Online Mahasiswa Fakultas Ekonomi Universitas Riau, 4(1), 1699-1713.

Niliani, D. (2019). Implementasi Manajemen Aset, Sumber Daya Manusia Pengelola Aset, Serta Sistem Pengendalian Internal Pemerintah Dan Pengaruhnya Terhadap Kualitas Pelaporan Keuangan. JRA: Jurnal Riset Akuntansi Tirtayasa, 4(2), 102-113. Retrieved from https://jurnal.untirta.ac.id/index.php/JRA/article/view/5650

Noviani, A., \& Hendarsyah, D. (2020). Ketepatan Waktu Pelaporan Keuangan: Sistem Pengendalian Internal Dan Sistem Informasi Pengelolaan Keuangan Daerah. Jurnal Akuntansi, Ekonomi Dan Manajemen Bisnis, 8(2), 206-213. https://doi.org/10.30871/jaemb.v8i2.2477

Philadhelphia, I. S., Suryaningsum, S., \& Sriyono, S. (2020). Pengaruh Kompetensi Sumber Daya Manusia, Standar Akuntansi Pemerintah, Good Governance, Dan 
Sistem Pengendalian Internal Terhadap Kualitas Laporan Keuangan Pemerintah Daerah. J-ISCAN: Journal of Islamic Accounting Research, 2(1), 17-35. Retrieved from https://ejurnal.iainlhokseumawe.ac.id/index.php/J-ISCAN/article/view/777

Pravasanti, Y. A., \& Ningsih, S. (2019). Pengaruh Kualitas Aparatur Daerah, Sistem Akuntansi Keuangan Daerah, Dan Pemanfaatan Teknologi Informasi Terhadap Kualitas Laporan Keuangan Pemerintah Daerah (Studi Empiris Satuan Kerja Perangkat Daerah Kabupaten Sukoharjo). Aktsar: Jurnal Akuntansi Syariah, 2(2), 199-214. https://doi.org/10.21043/aktsar.v2i2.6054

Presiden RI. (2005). Peraturan Pemerintah Republik Indonesia Nomor 56 Tahun 2005 Tentang Sistem Informasi Keuangan Daerah. Retrieved from https://peraturan.bpk.go.id/Home/Download/39000/PP NO 56 TH 2005.pdf

Presiden RI. (2008). Peraturan Pemerintah Republik Indonesia Nomor 60 Tahun 2008 Tentang Sistem Pengendalian Intern Pemerintah. Retrieved from Pemerintah Republik Indonesia website: http://www.bpkp.go.id/public/upload/unit/sakd/files/PP60Tahun2008_SPIP.pdf

Presiden RI. (2010). Peraturan Pemerintah Republik Indonesia Nomor 71 Tahun 2010 Tentang Standar Akuntansi Pemerintahan. Retrieved from http://www.djpk.kemenkeu.go.id/attach/post-pp-no-71-tahun-2010-tentang-standarakuntansi-pemerintahan/PP71.pdf

Putri, W. S., \& Hendarsyah, D. (2020). Pengaruh Sistem Pengendalian Internal Terhadap Penerapan Sistem Komputerisasi Haji Terpadu (SISKOHAT): Studi Pada Kantor Kementerian Agama Kabupaten Bengkalis. Inovbiz: Jurnal Inovasi Bisnis, 8(1), 52. https://doi.org/10.35314/inovbiz.v8i1.1252

Renyowijoyo, M. (2013). Akuntansi Sektor Publik Organisasi Non Laba. Jakarta: Mitra Wacana Media.

Rohmah, L., Askandar, N. S., \& Sari, A. F. K. (2020). Pengaruh Pemahaman Standar Akuntansi Pemerintah, Pemanfaatan Sistem Informasi Akuntansi Keuangan Daerah Dan Sistem Pengendalian Internal Terhadap Kualitas Laporan Keuangan Pemerintah Daerah Kota Malang. Jurnal Ilmiah Riset Akuntansi, 9(05), 43-51. Retrieved from http://www.riset.unisma.ac.id/index.php/jra/article/view/8286

Sholohah, S. A., Sulistyawati, A. I., \& Santoso, A. (2019). Kualitas Laporan Keuangan Dan Faktor-Faktor Yang Mempengaruhinya. IAJ: Indonesia Accounting Journal, 1(2), 45-56. https://doi.org/10.32400/iaj.26622

Sihite, R. N., \& Holiawati, H. (2017). Standar Akuntansi Pemerintahan, Sistem Pengendalian Internal, Kompetensi Staf Akuntansi Dan Kualitas Laporan Keuangan. Jurnal ASET (Akuntansi Riset), 9(2), 81-92. https://doi.org/10.17509/jaset.v9i2.9231

Sikumbang, M., Pakaya, L., \& Blongkod, H. (2020). Pemanfaatan Teknologi Informasi, Kualitas SDM, dan Sistem Pengendalian Intern Terhadap Kualitas Laporan Keuangan Studi pada OPD Provinsi Gorontalo. Jambura Accounting Review, 1(1), 36-47. 
https://doi.org/10.37905/jar.v1i1.8

Siregar, S. (2013). Metodologi Penelitian Kuantitatif, Cetakan Pertama. Jakarta: Kencana.

Sugiyono. (2014). Metode Penelitian Kuantitatif Kualitatif dan R\&D. Bandung: Alfabeta.

Suprihatin, N. S., \& Ananthy, A. A. (2019). Pengaruh Penerapan Standar Akuntansi Pemerintah Dan Sistem Informasi Akuntansi Terhadap Kualitas Laporan Keuangan. Jurnal Riset Akuntansi Terpadu, 12(2), 242-252. https://doi.org/10.35448/jrat.v12i2.6218

Tampubolon, F. M., \& Hasibuan, A. B. (2019). Pengaruh Komitmen Organisasi, Kompetensi Sumber Daya Manusia dan Pemanfaatan Teknologi Informasi Terhadap Kualitas Laporan Keuangan Pemerintah. OIKOS: Jurnal Kajian Pendidikan Ekonomi Dan Ilmu Ekonomi, 3(1), 55-65. https://doi.org/10.23969/oikos.v3i1.1415

Tangko, I., Falah, S., \& Pangayow, B. J. C. (2019). Pengaruh Sistem Akuntansi Pemerintah Daerah, Kompetensi Sumber Daya Manusia Dan Pemanfaatan Teknologi Informasi Terhadap Kualitas Laporan Keuangan Pemerintah Daerah Kabupaten Pegunungan Bintang. Jurnal Akuntansi, Audit Dan Aset (AAA), 2(1), 60-76. Retrieved from http://ejournal.maksi-uncen.ac.id/index.php/maksi/article/view/27

Taviana, T., \& Riharjo, I. B. (2020). Peningkatan Kualitas Laporan Keuangan Pemerintah Daerah: Kompetensi Sumber Daya Manusia Sebagai Faktor Pemoderasi. Jurnal Ilmu Dan Riset Akuntansi (JIRA), 9(1), 1-23. Retrieved from http://jurnalmahasiswa.stiesia.ac.id/index.php/jira/article/view/2763

Uno, H. B., \& Lamatenggo, N. (2011). Teknologi Komunikasi dan Informasi Pembelajaran. Jakarta: PT. Bumi Aksara.

Wulandari, T., \& Hendarsyah, D. (2020). Pengaruh Penerapan SIMSKRD Terhadap Kualitas Laporan Keuangan Retribusi Izin Gangguan. Aktiva: Jurnal Akuntansi Dan Investasi, 4(1), 45-57. https://doi.org/10.35835/aktiva.v5i1.831

Yanti, N. S., Made, A., \& Setiyowati, S. W. (2020). Pengaruh Penerapan Standar Akuntansi Pemerintah, Pemanfaatan Sistem Informasi Akuntansi Dan Pengawasan Keuangan Terhadap Kualitas Laporan Keuangan Pemerintah Daerah. Jurnal Riset Mahasiswa Akuntansi, 8(1), 1-8. https://doi.org/10.21067/jrma.v8i1.4455

Yusuf, M. (2014). Metodologi Penelitian Kuantitatif, Kualitatif \& Penelitian Gabungan. Jakarta: Kencana. 